International Journal of Pharmaceutics \& Pharmacology

EDW SER

Available Online: https://ijpp.edwiserinternational.com

\title{
Intracellular Pharmacokinetics of PARP Inhibitors in Breast and Ovarian Cancer Cells and Correlation to Drug Action: A Review
}

\author{
Phiri Margaret ${ }^{1,2}$, Li Duo $^{1}$, Li Tengfei ${ }^{1}$, Li Xianjing ${ }^{1,2}$, Gao Huaye ${ }^{1,2}$, Ding Li $^{1,2 \# *}$ and Chang Shu ${ }^{1 \# *}$ \\ ${ }^{1}$ Department of Pharmaceutical Analysis, China Pharmaceutical University, Nanjing 210009, China \\ ${ }^{2}$ Nanjing Clinical Tech Laboratories Inc., 18 Zhilan Road, Jiangning District, Nanjing 211000, PR China \\ \#Both authors contributed equally
}

Article info

Received 07 February 2020

Revised 27 February 2020

Published 12 March 2020

*Corresponding author: Ding Li and Chang Shu, Department of Pharmaceutical Analysis, China Pharmaceutical University, 24 Tongjiaxiang, Nanjing China; Email: maggie82dfb@yahoo.com

\begin{abstract}
Recently Poly (ADP-Ribose) Polymerase inhibitor (PARPi) drugs were approved by the FDA for clinical use in breast and ovarian cancer, recurrent epithelial ovarian, fallopian tube, or primary peritoneal cancer. Olaparib an oral formulation approved for the treatment of patients with BRCA mutation and recurrent ovarian cancer; has shown to provide clinically significant benefit. Inhibition of PARP results in accumulation of single-strand breaks, leading to formation of double-strand breaks. Olaparib, a small molecule, selectively binds and inhibits Poly (ADPRibose) Polymerase enzyme, inhibiting its mediated repair of single-strand DNA breaks. Poly (ADP-Ribose) Polymerase inhibition enhances cytotoxicity of DNA damaging agents and reverses tumor cell chemoresistance and radio resistance. There has been limited research on the quantification of anti-cancer drugs intracellularly; very few studies have attempted to quantify Olaparib intracellularly. For the first time, intercellular quantification of PARP inhibitor was reported in two studies involving oral dosage form and the other nano-delivery system, allowing for quantification of Olaparib distribution in the nuclei, cytoplasm, liver, kidney, plasma, and urine. This review, covers articles and reports from 1992 to 2019 and is aimed at highlighting the increasing importance of intracellular quantification of anti-cancer drugs using PARP inhibitors as examples, due to limited research done on this group of drugs, only Olaparib has been reported have been determined intracellularly.
\end{abstract}

Keywords: HPLC-UV-DAD; Method validation; Intracellular drug concentration; PARP inhibitors; Olaparib

\section{Introduction}

Breast and ovarian cancer are ranked among the topmost significant types of cancer in terms of rates of incidences and mortality in 2018 by the world health organization. Together, these two cancer types are responsible for a third of mortality and prevalence worldwide. An estimation of 2.1 million diagnoses was made in 2018, $11.6 \%$ of total cancer incidence burden worldwide [1]. Unfortunately, breast and ovarian cancer incidences are still rising to date. In the recent few decades, substantial progress has been made to understand breast cancer molecular pathways, leading to development of more individualized therapies [2]. Despite this, the metastatic breast cancer 5-year survival rate remains low [3]. Breast cancer is a very heterogeneous disease, with broad differentiation and clinical behaviors [4]. Breast cancer is classified based 
on immunohistochemical features: Human Epidermal Growth Factor Receptor 2 (HER2)-positive, Hormone Receptor (HR)-positive, and Triple-Negative (TN) tumors [5]. TNBCs comprise about $15 \%$ of breast cancers overall, about $70 \%$ in germline BRCAl mutation, and $20 \%$ in BRCA2 mutation carriers (TNBCs) characterized by the absence of estrogen receptor (ER), progesterone receptor (PR), and HER2 expression [6]. TNBC, compared to other types of breast cancer, has a high reoccurrence rate and a poor 5-year prognosis [7]. Targeted therapy such as endocrine therapy or Trastuzumab are unable to treat TNBCs because they lack cellular targets [8]; hence treatment of TNBC is a major challenge. In this review, we aimed at highlighting the increasing importance of intracellular quantification of anti-cancer drugs for enhancement of efficacy, reducing adverse effects, increase tolerability and new ways to maintain sensitivity and minimize resistance using PARP inhibitors as examples. Due to limited research done on this group of drugs, only Olaparib has been determined intracellularly in the recent analysis.

\section{Pathophysiology, causes and molecular pathways of breast carcinogenesis}

When breast cells come into contact or interact with external factors, and due to genetic susceptibility they become cancerous [2]. Normal cells multiply and divide as many times as needed, then stop, attach to other cells and then stay in place in tissues. When cells lose the ability to divide, attach to other cells, remain in the right place and die inappropriate time, they become cancerous. The typical cell dies when they have lived their life and are no longer needed, until this time they are protected from cell death by protein clusters and pathways (figure1).

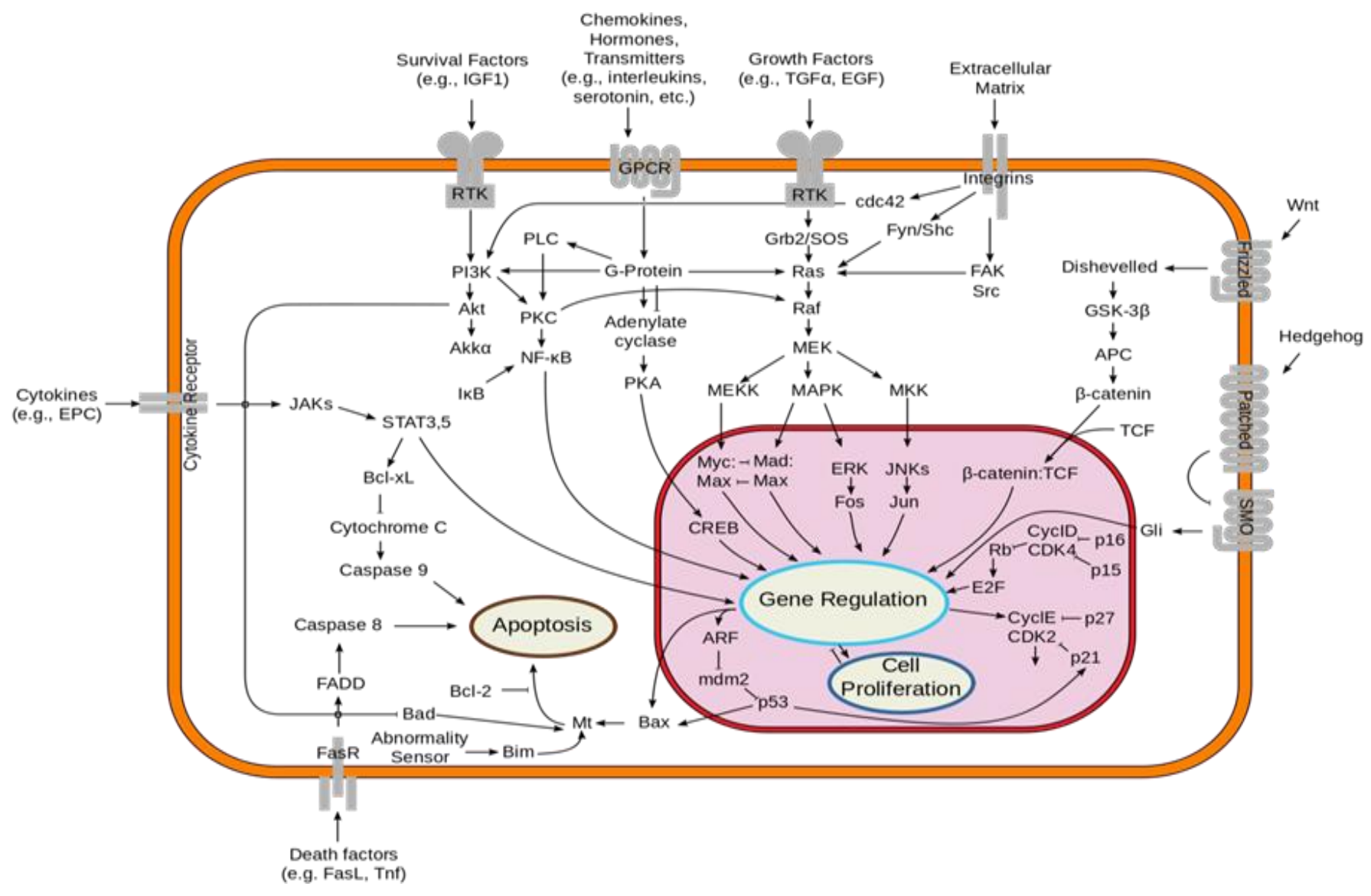

Figure 1: Signal transduction pathway. 
Two protective channels are the PI3K/AKT and the RAS/MEK/ERK pathway. In specific instances, the genes on these protective pathways are mutated causing the pathway to be turned permanently "on" meaning the cell then becomes incapable of cell death at the time it is no longer needed. This step in combination with other mutations is what causes cancer. Normally, the $\mathrm{PI} 3 \mathrm{~K} / \mathrm{AKT}$ pathway is turned off by the PTEN protein when the cell is ready for cell suicide. When the PTEN protein gene is mutated, the cancer cells avoid apoptosis because the PI3K/AKT pathway is stuck in the "on" position [9]. Estrogen exposure is experimentally identified as a link to mutations leading to breast cancer $[10,11]$. In the interaction between epithelial cells and stromal cells, abnormal growth factor signaling can facilitate cancerous cell growth [12, 13]. Overexpression of leptin leads to increased cell proliferation in adipose tissue and breast cancer [14]. Hereditary breast-ovarian cancer syndrome is the familial tendency to develop these cancers. The BRCA mutations present with a 15-40\% lifeime risk od ovarian cancer and $60-85 \%$ risk of breast cancer. Mutations that occur due to drugs mechanisms to correct DNA such as p53, BRCA and BRCA2 acquired after birth or inherited, are associated wuth cancer. However, there is strong evidence between carrier families, enviromental causes and inherited mutations in BRCA1 and BRCA2 genes [15-18].

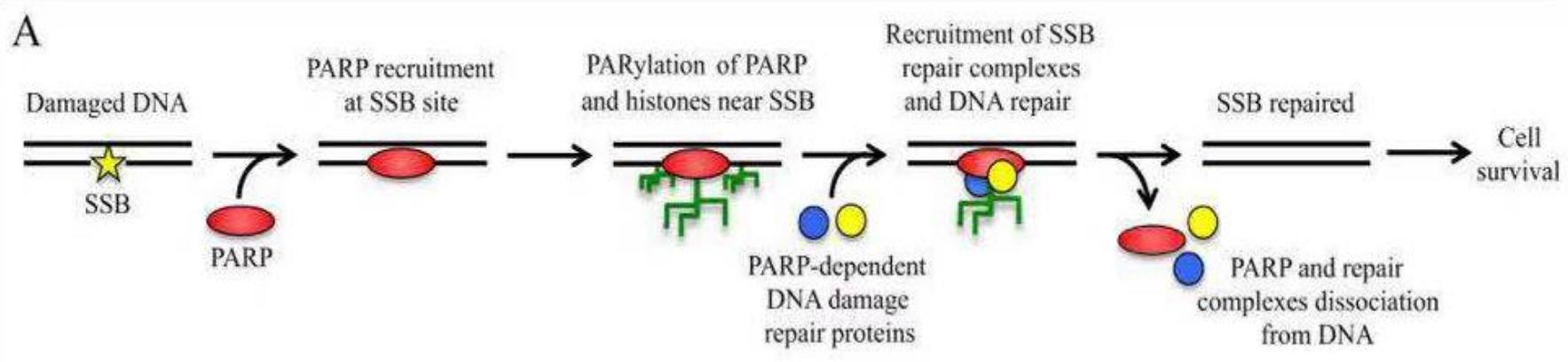

B

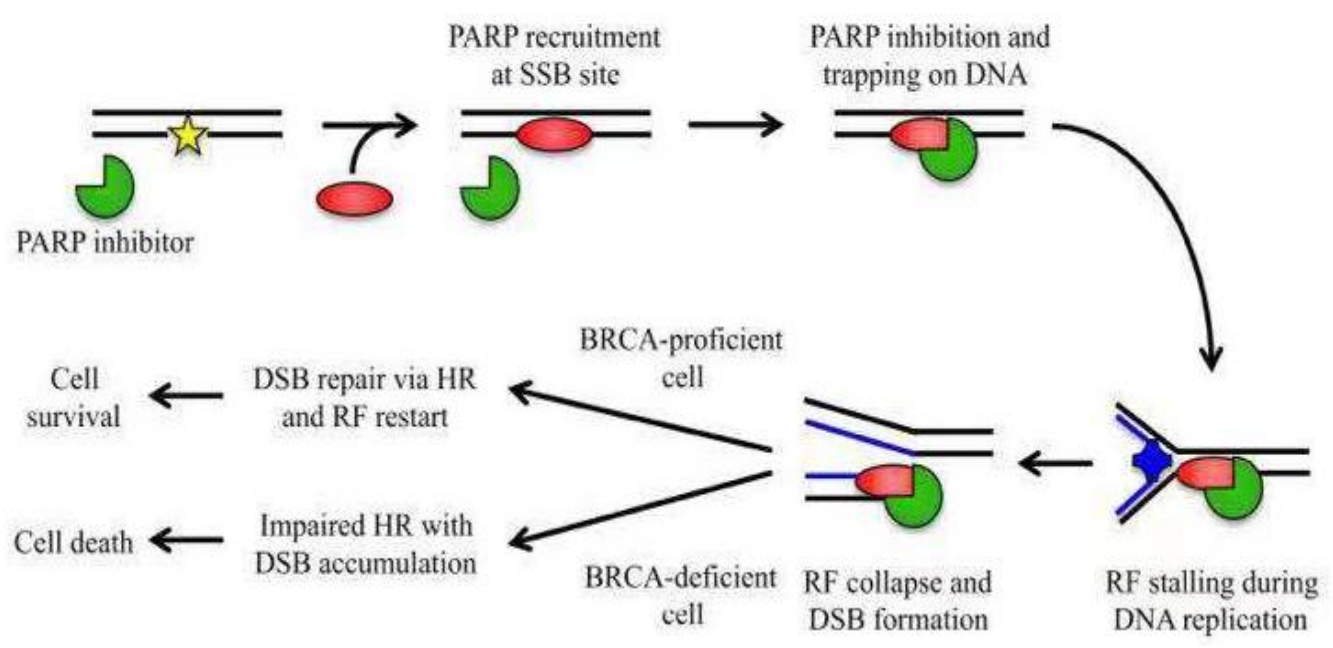

Figure 2: Current model for PARP role in DNA damage repair and PARP inhibition - BRCA mutation synthetic lethality. A: When single-strand break (SSB) is detected in normal cell. B: In the presence of PARP inhibitors, PARPs recruited to DNA-damage sites are no longer able to activate PARP-dependent repair systems [33].

DNA damage are as a result of carcinogens often requiring repairs by pathways with BRCA1 and BRCA2 $[19,20]$. However, only 2 to $3 \%$ of all breast cancers are due to variations in BRCA genes [21]. Levin et al., states that half of inherited breast-ovarian cancer involve unknown genes and is not inevitable for all
BRCA1 and BRCA2 mutation carriers. The protein GATA-3 controlling the expression of ER and other genes associated with epithelial distinction. The depletion of GATA-3 leads to poor prognosis and loss of differentiation due to cancer cell metastasis and invasion [22]. 


\section{PARPs and DNA damage repair}

Poly (Adenosine Diphosphate-Ribose) Polymerase (PARP) is a single strand DNA damage recognition repair protein. Accumulation of single strand breaks due to inhibition of PARP leads to accumulation of double strand DNA breaks. Cells with BRCA mutation are not able to repair DSBs hence are unable to undergo apoptosis [23] (figure 2).

\section{PARP inhibitors}

PARPi drugs recently been approved by the FDA for clinical use in breast and ovarian cancer. An oral PARP inhibitor, Olaparib has been approved for treatment of ovarian cancer and a BRCA mutation [24-27].

Table 1: List of PARP inhibitors.

\begin{tabular}{|c|c|c|c|c|c|c|}
\hline $\begin{array}{l}\text { Compound } \\
\text { Company }\end{array}$ & $\begin{array}{l}\text { MW } \\
(\mathrm{g} / \mathrm{mol})\end{array}$ & Structure & $\begin{array}{l}\mathbf{K i} \\
\text { (nM) }\end{array}$ & $\begin{array}{l}\mathrm{IC}_{50} \\
(\mathbf{n M})\end{array}$ & Status in clinical development & References \\
\hline $\begin{array}{l}\text { Olaparib } \\
\text { (AZD2281) } \\
\text { AstraZeneca }\end{array}$ & 435.08 & & $\mathrm{n} / \mathrm{a}$ & $\begin{array}{l}\text { PARP- } \\
1: 5 \\
\text { PARP- } \\
2: 1\end{array}$ & $\begin{array}{l}\text { FDA approved for advanced ovarian } \\
\text { cancer with gBRCAmut with } \geq 3 \\
\text { prior lines of chemotherapy in } 2014 \text {. } \\
\text { For recurrent epithelial ovarian, } \\
\text { fallopian tube, or primary peritoneal } \\
\text { cancer maintenance treatment in adult } \\
\text { patients with incomplete or partial } \\
\text { response to platinum-based } \\
\text { chemotherapy in } 2017 \text {. }\end{array}$ & {$[34,35]$} \\
\hline $\begin{array}{l}\text { Rucaparib } \\
\text { (CO-338) } \\
\text { Clovis }\end{array}$ & 421.36 & & $\begin{array}{l}\text { PARP- } \\
1: 1.4 \\
\text { PARP- } \\
2: \mathrm{n} / \mathrm{a}\end{array}$ & $\begin{array}{l}\text { PARP- } \\
1: 0.8 \\
\text { PARP- } \\
2: 0.5\end{array}$ & $\begin{array}{l}\text { FDA approved for advanced ovarian } \\
\text { cancer with gBRCAmut or } \\
\text { sBRCAmut with } \geq 2 \text { lines of } \\
\text { chemotherapy in } 2016 \text {. } \\
\text { For recurrent epithelial ovarian, } \\
\text { fallopian tube, or primary peritoneal } \\
\text { cancer maintenance treatment in adult } \\
\text { patients with incomplete or partial } \\
\text { response to platinum-based } \\
\text { chemotherapy in } 2018 \text {. }\end{array}$ & {$[36,37]$} \\
\hline $\begin{array}{l}\text { Niraparib } \\
\text { (MK-4827) } \\
\text { Tesaro }\end{array}$ & 320.39 & & $\mathrm{n} / \mathrm{a}$ & $\begin{array}{l}\text { PARP- } \\
1: 3.8 \\
\text { PARP- } \\
2: 2.1\end{array}$ & $\begin{array}{l}\text { FDA approved for the recurrent } \\
\text { epithelial ovarian, fallopian tube, or } \\
\text { primary peritoneal cancer who have a } \\
\text { complete or partial response to } \\
\text { platinum chemotherapy }\end{array}$ & [38] \\
\hline
\end{tabular}




\begin{tabular}{|c|c|c|c|c|c|c|}
\hline $\begin{array}{l}\text { Talazoparib } \\
\text { (BMN-673) } \\
\text { Pfizer }\end{array}$ & 380.35 & F & $\begin{array}{l}\text { PARP- } \\
1: 1.2 \\
\text { PARP- } \\
2: 0.85\end{array}$ & $\begin{array}{l}\text { PARP- } \\
1: 0.57 \\
\text { PARP- } \\
2: \mathrm{n} / \mathrm{a}\end{array}$ & $\begin{array}{l}\text { In Phase III study as monotherapy in } \\
\text { patients with locally advanced or } \\
\text { metastatic breast cancer with } \\
\text { gBRCAmut in } 2017\end{array}$ & \begin{tabular}{|l|} 
[39] \\
\end{tabular} \\
\hline $\begin{array}{l}\text { Veliparib } \\
\text { (ABT-888) }\end{array}$ & 244.29 & & $\begin{array}{l}\text { PARP- } \\
1: 5.2 \\
\text { PARP- } \\
2: 2.9\end{array}$ & $\mathrm{n} / \mathrm{a}$ & $\begin{array}{l}\text { In Phase III studies as combination } \\
\text { therapy with chemotherapy in } \\
\text { patients with breast and ovarian } \\
\text { cancer with gBRCAmut or } \\
\text { sBRCAmut and lung cancer. }\end{array}$ & [40] \\
\hline
\end{tabular}

The OlympiAD trial designed to compare the safety and efficacy of Olaparib with the physician's choice of standard therapy, single-agent chemotherapy, among patients with a germline BRCA mutation and HER2negative metastatic breast cancer. Phase. Olaparib showed clinical efficacy in both breast and ovarian cancer in phase 1 [28]. Talazoparib at the recommended dose of $1.0 \mathrm{mg} /$ day demonstrated single agent antitumor activity and was well tolerated in phase 2 . Talazoparib also demonstrated encouraging activity in patients with gBRCA1/2mMBC, who previously received platinumbased therapy or various chemotherapeutic regimens [28-32].

\section{Clinical pharmacokinetics of PARP inhibitors}

The clinical pharmacokinetics of PARP inhibitors have been summarized in table 2. Olaparib [41], Rucaparib [42], Niraparib [43], Talazoparib [44] and Veraparib [45].

\section{Methodological considerations}

Olaparib (figure 4), Veliparib, Niraparib and Rucaparib; PARP inhibitors in combination or as standalone therapy have recently reached advanced clinical trials in ovarian and breast cancers. The first to gain regulatory approval for treatment of BRCA-mutated ovarian cancer by European Commission in 2014 and FDA in 2015 was Olaparib [46-48]. The sensitivity of tumor cells to PARP inhibitors has been shown to vary widely in preclinical and clinical studies hence treatment efficacy needs to be optimized. The amount of PARP inhibitors that reaches cell interior compartments, influences sensitivity and effectiveness of therapy as PARP is an intracellular target [49].

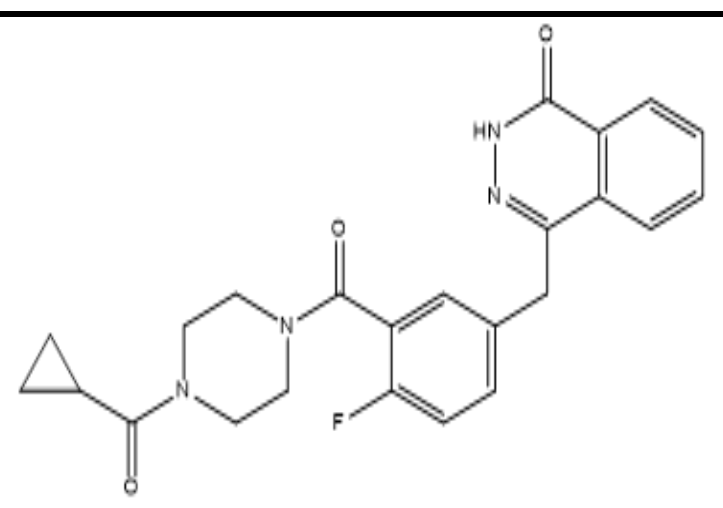

Figure 4: Chemical structure of the PARP I Olaparib. 
Citation: Phiri M, Duo L, Tengfei L, et al. Intracellular Pharmacokinetics of PARP Inhibitors in Breast and Ovarian Cancer Cells and Correlation to Drug Action: A Review. Int J Pharm Pharmacol 2020; 4: 139. doi: $\underline{10.31531 / 2581-3080.1000139}$

Table 2: Summary of pharmacokinetic parameters of PARP inhibitors.

\begin{tabular}{|c|c|c|c|c|c|c|c|}
\hline Drug & $\mathbf{T}_{\max }(\mathbf{h})$ & $T_{1 / 2}(h)$ & 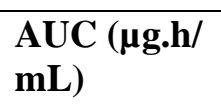 & $\begin{array}{l}\mathrm{C}_{\max } \\
(\mu \mathrm{g} / \mathrm{mL})\end{array}$ & $\begin{array}{l}\text { CL/F } \\
(\mathbf{L} / \mathbf{h})\end{array}$ & $\mathbf{V z} / \mathbf{F}$ & References \\
\hline $\begin{array}{l}\text { Olaparib capsule } \\
\text { formulation } 300 \mathrm{mg}\end{array}$ & \begin{tabular}{|l}
1.49 \\
$3.05)$
\end{tabular} & $\begin{array}{l}13.02 \\
(8.23)\end{array}$ & $55.20(67.4)$ & $8.05(24.3)$ & \begin{tabular}{|l|}
6.36 \\
$(3.47)$
\end{tabular} & $\begin{array}{l}112.1 \\
(59.84)\end{array}$ & [71] \\
\hline $\begin{array}{l}\text { Olaparib tablet formulation } \\
300 \mathrm{mg} \text { single dose (fasted) }\end{array}$ & $\begin{array}{l}1.50 \\
(0.50-5.85)\end{array}$ & $\begin{array}{l}12.2 \\
(5.31)\end{array}$ & $\begin{array}{l}43.6(54.3) \\
{\left[A U C_{t}\right]} \\
43.0(55.2) \\
{\left[A U C_{\infty}\right]}\end{array}$ & $7.00(35.0)$ & $\begin{array}{l}7.95 \\
(4.23)\end{array}$ & $\begin{array}{l}146 \\
(142)\end{array}$ & [72] \\
\hline $\begin{array}{l}\text { Olaparib tablet formulation } \\
300 \mathrm{mg} \text { single dose (fed) }\end{array}$ & \begin{tabular}{|l|}
4.00 \\
$(1.00-12.0)$
\end{tabular} & $\begin{array}{l}12.2 \\
(5.31)\end{array}$ & $\begin{array}{l}46.0(56.6) \\
{\left[\mathrm{AUC}_{\mathrm{t}}\right]} \\
45.4(57.1) \\
{\left[\mathrm{AUC}_{\infty}\right]}\end{array}$ & $5.48(40.5)$ & \begin{tabular}{|l|}
7.55 \\
$(3.99)$
\end{tabular} & $\begin{array}{l}127 \\
(107)\end{array}$ & [72] \\
\hline $\begin{array}{l}\text { Veliparib monotherapy } 40 \\
\text { mg (4 x } 10 \mathrm{mg} \text {, fasting) }\end{array}$ & $1.2 \pm 0.8$ & $\begin{array}{ll}5.9 & \pm \\
1.3 & \end{array}$ & $\begin{array}{l}2.23 \pm 0.82 \\
{\left[\mathrm{AUC}_{\mathrm{t}}\right]} \\
2.43 \pm 1.07 \\
{\left[\mathrm{AUC}_{\infty}\right]}\end{array}$ & $0.36 \pm 0.13$ & $\begin{array}{ll}19.0 & \pm \\
7.36\end{array}$ & NA & [73] \\
\hline $\begin{array}{l}\text { Veliparib monotherapy } 40 \\
\mathrm{mg}(4 \times 10 \mathrm{mg} \text {, fed })\end{array}$ & $1.2 \pm 0.7$ & $\begin{array}{ll}5.8 & \pm \\
1.2 & \end{array}$ & $\begin{array}{l}2.45 \pm 0.93 \\
{\left[\mathrm{AUC}_{\mathrm{t}}\right]} \\
2.65 \pm 1.17 \\
{\left[\mathrm{AUC} \mathrm{C}_{\infty}\right]}\end{array}$ & $0.37 \pm 0.12$ & $\begin{array}{ll}17.3 & \pm \\
6.41 & \end{array}$ & NA & [73] \\
\hline $\begin{array}{l}\text { Veliparib monotherapy } 40 \\
\text { mg (1 x } 40 \text { mg, fasting) }\end{array}$ & $1.3 \pm 0.9$ & $\begin{array}{ll}5.8 & \pm \\
1.3 & \end{array}$ & $\begin{array}{l}2.24 \pm 0.98 \\
{\left[\mathrm{AUC}_{\mathrm{t}}\right]} \\
2.45 \pm 1.24 \\
{\left[\mathrm{AUC}_{\infty}\right]}\end{array}$ & $0.34 \pm 0.12$ & $\begin{array}{ll}19.5 & \pm \\
7.66 & \end{array}$ & NA & [73] \\
\hline $\begin{array}{l}\text { Veliparib monotherapy } 40 \\
\text { mg }(1 \text { x } 40 \mathrm{mg} \text {, fed })\end{array}$ & $2.5 \pm 1.1$ & $\begin{array}{ll}5.8 & \pm \\
1.4 & \end{array}$ & $\begin{array}{l}2.14 \pm 0.80 \\
{\left[\mathrm{AUC}_{\mathrm{t}}\right]} \\
2.35 \pm 1.06 \\
{\left[\mathrm{AUC}_{\infty}\right]}\end{array}$ & $0.28 \pm 0.09$ & $\begin{array}{ll}19.7 & \pm \\
7.51 & \end{array}$ & NA & [73] \\
\hline Veliparib metabolite M8 & $\begin{array}{ll}2.4 & (3.5- \\
9.8) & \end{array}$ & - & $\begin{array}{l}0.3-1.9 \\
{\left[\mathrm{AUC} \mathrm{C}_{\mathrm{int}}\right]}\end{array}$ & $\begin{array}{l}0.011 \\
(0.007- \\
0.014)\end{array}$ & NA & NA & [74] \\
\hline Niraparib 300 mg/day & $\begin{array}{|lr|}3.1 & (2.0- \\
6.1) & \end{array}$ & $\mathrm{a}$ & $\begin{array}{l}14.117 \\
\left(\mathrm{AUC}_{24}\right)^{\mathrm{b}}\end{array}$ & $1.921^{\mathrm{b}}$ & NA & NA & [75] \\
\hline $\begin{array}{l}\text { Niraparib metabolite: } \\
\text { unlabeled M1 plasma }\end{array}$ & 9.02 & 78.4 & $41.2\left(\mathrm{AUC}_{\infty}\right)$ & 476 & NA & NA & [76] \\
\hline \multicolumn{8}{|c|}{ 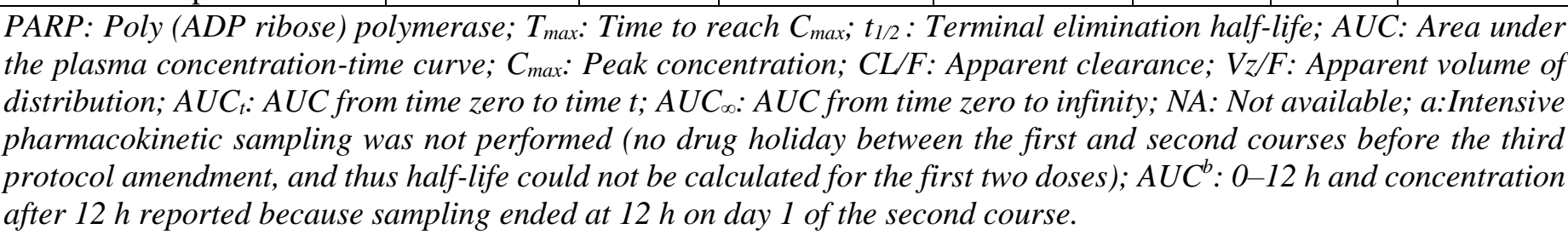 } \\
\hline
\end{tabular}

Intracellular drug disposition is determined by drug metabolizing enzymes and transporting proteins. This was discovered during an early preclinical trial to be important as an essential resistance mechanism for
PARPi [50-53]. Intercellular quantification methods for PARP inhibitors in tumor cells offer the advantage of dose optimization and improved predictions of drug response. To evaluate the relationship between PARP 
inhibitors intracellular concentration and treatment efficacy, reliable quantification methods are warranted. Previously intercellular quantification of drugs was challenging and radiolabeled analog (are not readily available) were relied on to assist in quantification [54, 55]. Therefore, LC-MS/MS is a susceptible and specific technique for low drug level detection of drugs in cells, but sample preparations are time consuming and instruments are expensive [56].

LC-MS/MS methods for quantification of PARPi in human plasma, cell culture medium, brain and tumor cells were reported for the first time [57, 58]. Oplustilova et al. reported intracellular concentration of an Olaparib analog by LC-MS/MS but offered no details on analytical methods used [62]. Flow cytometric analysis was used for single-cell analysis and assessment of intracellular concentration of fluorescent drugs [59, 63-65]. This technique is in the early development stage, and few drugs have intrinsic fluorescence. With available equipment, HPLC with UV-DAD analysis both allow for sensitive quantitation of numerous compounds [66].

Once a drug enters a cell often facilitated by transporters, it accumulates in organelles. When in the cytoplasm, essential molecules accumulate in cell organelles. To predict a drug's pharmacologic impact accurately, information about its level at the target site is essential but is difficult to determine. Techniques combining mass spectrometry and imaging techniques such as matrix-assisted laser desorption/ionization, secondary ion mass spectrometry (SIMS), and Nano SIMS offer promise in combating this problem [49]. The main limitation in intercellular drug quantification is lack of suitable methods and techniques to determine drug distribution within cells [67]. New methods of intercellular drug quantification are on the horizon in hopes to complement advances in time-lapse confocal microscopy used to study mannerisms of intracellular organelles in living and intact animal cells [67]. For a drug to elicit its pharmacological action it must reach the desired target site with effective and substantial concentration, in anticancer therapy many of these targets are intracellular. The study and research of the distribution of drugs into and within the cell are most neglected research areas in pharmacokinetics, pharmacology and therapeutics [69]. The use of drug concentration in plasma, rather than dose, in pharmacology, therapeutics and safety assessment although being a critical step forward, urgently needs to be replaced by information about intracellular concentrations and distribution. This review aims emphasize the increasing need for determination of drug concentrations and outcomes within the cell and its organelles. This topic has become of increasing importance in anticancer drug discovery as cancer drugs have intercellular drug targets such as mitochondria, oligonucleotides, antibodies and lysosomes [68].

\section{Mechanisms influencing intracellular accumulations}

Intracellular drug accumulation is influenced by drug transporting proteins and enzymes whose expressions are cell and tissue dependent. Intracellular drug disposition is determined by drug metabolizing enzymes and transporting proteins [79, 80]. Cell interior drug concentration is increased by uptake transporters and reduced by efflux enzymes and transporters [80-83] (figure 5).

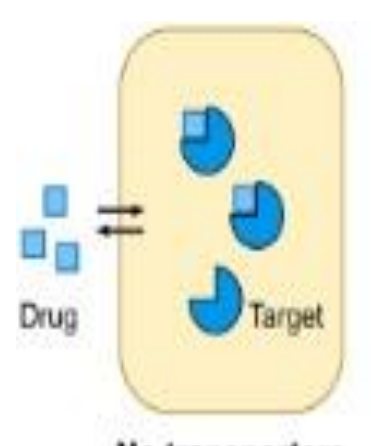

No transporters

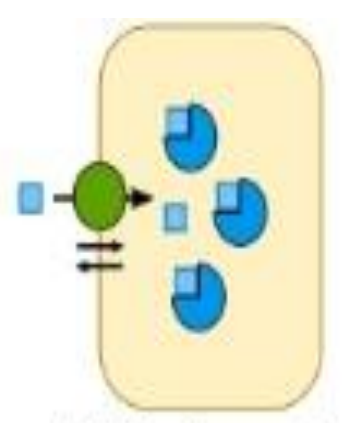

Uptake transporter Higher $F_{\mathrm{k}}$.
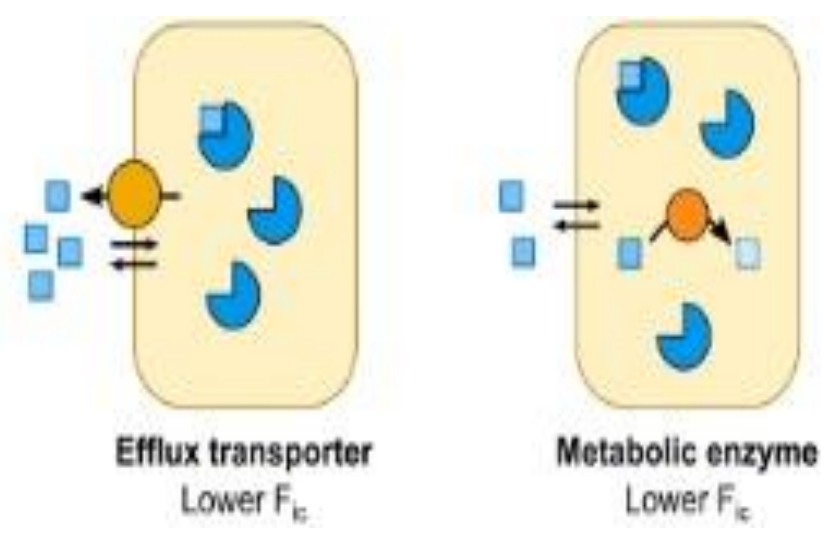

Figure 5: Impact of drug-transporting proteins and metabolizing enzymes on intracellular drug bioavailability $\left(\mathrm{F}_{\mathrm{ic}}\right.$, the fraction of externally added drug that is available to bind targets in the cell interior). 


\section{Clinical studies of intracellular concentrations}

This review was to highlight the increasing importance of intracellular quantification of anti-cancer drugs using PARP inhibitors as examples, due to limited research having been done on this group of drugs only Olaparib is reported to have been quantified intracellularly. For the first time, Olaparib was quantified inside cancer cells by use of HPLC-UV-DAD method capable of quantifying Olaparib in the whole cell in the range 200 - $2000 \mathrm{ng} / \mathrm{mL}$ [66]. The method allowed for quantification of drug concentration in cancer cells allowing for dose optimization and enhanced treatment response estimations [66]. In another recent study, a method was developed to quantify Olaparib encapsulated in ferritin-nano-carriers in nano drug development and applied to human BRCA-mutated cell model to quantify the Olaparib distribution. The method allowed, the quantification of low levels of Olaparib in different biological complex matrices for the first time; such as cell compartments, mouse tissues, plasma and urines, and precisely, the requirement of low volume of plasma and urine, rendered the particular method attractive for pharmacological research. In this method Olaparib was quantified within the range of $0.10-10$ $\mathrm{ng} / \mathrm{mL}$ in cells cytoplasm and culture medium, 0.50 - 10 $\mathrm{ng} / \mathrm{mL}$ in nuclei, $0.50-100 \mathrm{ng} / \mathrm{mL}$ in urine and plasma and $10-500 \mathrm{ng} / \mathrm{mL}$ in liver and kidney [77].

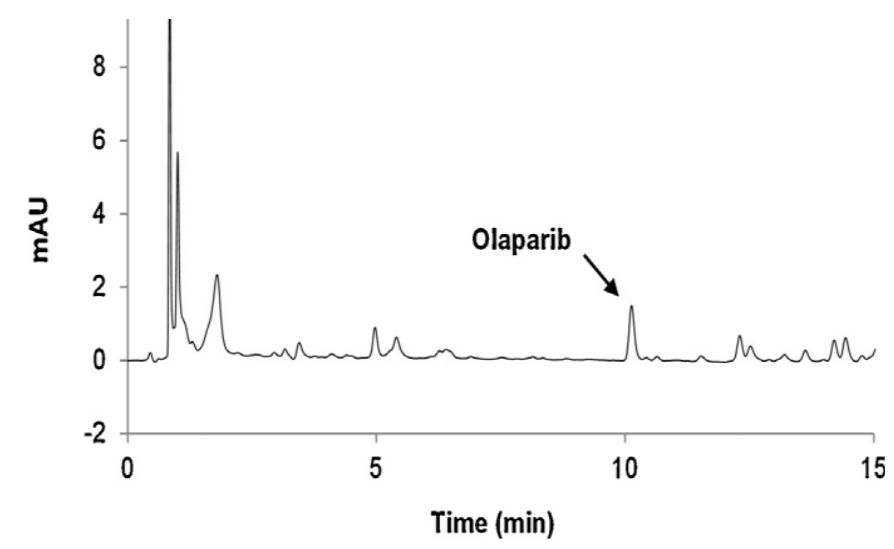

Figure 6: Typical HPLC chromatogram of a cell sample treated with Olaparib $50 \mu \mathrm{M}$ for $3 \mathrm{~h}[60]$.

\section{Method applicability}

The described method by Daumar et al. was developed and validated for intracellular determination of Olaparib in cultured cells. A suitable and sensitive method with limited sample preparation steps [64].
A reversed-phase HPLC with UV detection method, with readily available equipment, simple and rapid and inexpensive technique than tandem mass spectrometry and can be extended to other PARP inhibitors [60]. The method by daurmar compared with that published by Roth et al. [55], which is to date the highest sensitive and robust approach developed, in terms of recovery of analyte, range of calibration and sensitivity. Olaparib quantified over the calibration range of $200-2000$ $\mathrm{ng} / \mathrm{mL}$ with limit of quantification of $0.10 \mathrm{ng} / \mathrm{mL}$ intracellularly. Addition of urine, kidney and liver tissues makes this method flexible and broadly applicable to clinical and pharmacological studies of Olaparib elimination. Finally, a method based on nanodelivery system was also reported for the first time [71,78].

\section{Future Prospective}

The aim was to highlight the increasing importance of intracellular quantification for dose characterization, verification of drug accumulation at target site and mechanism of action of anti-cancer drugs using PARP inhibitors as examples, due to limited research done on this group of drugs only Olaparib has been reported and determined intracellularly. To Pharmacologists, pharmacokineticists and clinical pharmacologist, considerable attention needs to be drawn towards drug concentrations within the cell and other essential organelles within. The time has come to rethink the use of plasma concentration and volume at steady state as a critical way of explaining concentration in the extracellular fluid space/ drug distribution. This knowledge will go a long way in enhancing efficacy, reducing adverse effects, tolerability and new ways to maintain sensitivity and minimize resistance to PARP inhibitors. Knowledge and understanding of drug entry into specific tissues, cells and active site are becoming substantially crucial as a significant component of therapeutics, pharmacologic and clinical research.

\section{Conflict of Interest}

The authors declare no potential conflict of interest.

\section{Acknowledgement}

The authors gratefully acknowledge the financial support from National Natural Science Foundation of China (No. 81603072) and (No. 81573387). 


\section{References}

1. WHO. Latest global cancer data, Press Release $\mathrm{N}^{\circ}$ 263, 12 September. the international agency for research on cancer. 2018. Press Release. $\mathrm{N}^{\circ} 263$.

2. CDC. Division of Cancer Prevention and Control, Centers for Disease Control and Prevention. Centres for Disease Control. [Online] September 11, 2018. [Cited: March 21, 2019.] https://www.cdc.gov/cancer/breast/basic_info/wha t-is-breast-cancer.htm.

3. Liu M, Li Z, Yang J, et al. Cell-specific biomarkers and targeted biopharmaceuticals for breast cancer treatment. Cell Prolif 2016; 49: 409-420.

4. Marusyk A, Polyak K. Tumor heterogeneity: causes and consequences. Biochim Biophys Acta 2010; 1805: 105-117.

5. Tang Y, Wang Y, Kiani MF, et al. Classification, treatment strategy, and associated drug resistance in breast cancer. Clin Breast Cancer 2016; 16: 335343.

6. Jia LY, Shanmugam MK, Sethi G, et al. Potential role of targeted therapies in the treatment of triplenegative breast cancer. Anticancer Drugs 2016; 27 : 147-155.

7. Lehmann BD, Bauer JA, Chen $X$, et al. Identification of human triple-negative breast cancer subtypes and preclinical models for selection of targeted therapies. J Clin Investig 2011; 121: 2750-2767.

8. Liedtke C, Mazouni C, Hess KR, et al. Response to neoadjuvant therapy and long-term survival in patients with triple-negative breast cancer. J Clin Oncol 2008; 26: 1275-1281.

9. Lee A, Arteaga C, Smith I. $32^{\text {nd }}$ Annual CTRCAACR San Antonio Breast Cancer Symposium. Sunday Morning Year-End Review, San Antonio, Texan, USA, 2009.

10. Cavalieri E, Chakravarti D, Guttenplan J, et al. Catechol estrogen quinones as initiators of breast and other human cancers: implications for biomarkers of susceptibility and cancer prevention. Biochim Biophys Acta 2006; 1766: 63-78.

11. Farlex (2005) "Immunological Surveillance". The Free Dictionary. Retrieved 2008-02-10.

12. Haslam SZ, Woodward TL. Host microenvironment in breast cancer development: epithelial-cell-stromal-cell interactions and steroid hormone action in normal and cancerous mammary gland. Breast Cancer Res 2003; 5: 208-215.

13. Wiseman BS, Werb Z. Stromal effects on mammary gland development and breast cancer. Science 2002; 296: 1046-1049.
14. Jardé T, Perrier S, Vasson MP, et al. Molecular mechanisms of leptin and adiponectin in breast cancer. Eur J Cancer 2011; 47: 33-43.

15. Dunning AM, Healey CS, Pharoah PD, et al. A systematic review of genetic polymorphisms and breast cancer risk. Cancer Epidemiol Biomarkers Prev 1999; 8: 843-854.

16. Begg CB, Haile RW, Borg A, et al. Variation of breast cancer risk among BRCA1/2 carriers. JAMA 2008; 299: 194-201.

17. Patel KJ, Yu VP, Lee H, et al. Involvement of Brca2 in DNA repair. Mol Cell 1998; 1: 347-357.

18. Marietta C, Thompson LH, Lamerdin JE, et al. Acetaldehyde stimulates FANCD2 monoubiquitination, $\mathrm{H} 2 \mathrm{AX}$ phosphorylation, and BRCA1 phosphorylation in human cells in vitro: implications for alcohol-related carcinogenesis. Mutat Res 2009; 664: 77-83.

19. Theruvathu JA, Jaruga $P$, Nath RG, et al. Polyamines stimulate the formation of mutagenic 1 , N2-propanodeoxyguanosine adducts from acetaldehyde. Nucleic Acids Res 2009; 33: 35133520.

20. Wooster R, Weber BL, et al. Breast and ovarian cancer. N Engl J Med 2003; 348: 2339-2347.

21. Levin B, Lech D, Friedenson B, et al. Evidence that BRCA1- or BRCA2-associated cancers are not inevitable. Mol Med 2012; 18: 1327-1337.

22. Geenen JJJ, Linn SC, Beijnen JH, et al. PARP Inhibitors in the Treatment of Triple-Negative Breast Cancer. journal of clinical pharmacokinetics. Springer International Publishing AG 2017.

23. Kouros-Mehr H, Kim JW, Bechis SK, et al. GATA3 and the regulation of the mammary luminal cell fate. Curr Opin Cell Biol 2008; 20: 164-170.

24. Ledermann JA, Harter P, Gourley C, et al. Overall survival in patients with platinum-sensitive recurrent serous ovarian cancer receiving olaparib maintenance monotherapy: an updated analysis from a randomised, placebo-controlled, doubleblind, phase 2 trial. Lancet Oncol 2016; 17: 15791589

25. Pujade-Lauraine E, Ledermann JA, Penson RT, et al. Treatment with olaparib monotherapy in the maintenance setting significantly improves progression-free survival in patients with platinumsensitive relapsed ovarian cancer: results from the Phase III SOLO2 study. Presented at the Society of Gynecologic Oncology 48th Annual Meeting on Women's Cancer, National Harbor, MD, March 12-15, 2017. abstract.

26. Kaufman B, Shapira-Frommer R, Schmutzler RK, et al. Olaparib monotherapy in patients with 
Citation: Phiri M, Duo L, Tengfei L, et al. Intracellular Pharmacokinetics of PARP Inhibitors in Breast and Ovarian Cancer Cells and Correlation to Drug Action: A Review. Int J Pharm Pharmacol 2020; 4: 139. doi: $10.31531 / 2581-3080.1000139$

advanced cancer and a germline BRCA1/2 mutation. J Clin Oncol 2015; 33: 244-250.

27. Tutt A, Robson M, Garber JE, et al. Oral poly(ADPribose) polymerase inhibitor olaparib in patients with BRCA1 or BRCA2 mutations and advanced breast cancer: a proof-of-concept trial. Lancet 2010; 376: 235-244

28. Kaufman B, Shapira-Frommer R, Schmutzler RK, et al. Olaparib monotherapy in patients with advanced cancer and a germline BRCA1/2 mutation. J Clin Oncol 2015; 33: 244-250.

29. Turner NC, Telli ML, Rugo HS, et al. Final results of a phase 2 study of talazoparib (TALA) following platinum or multiple cytotoxic regimens in advanced breast cancer patients (pts) with germline BRCA1/2 mutations (ABRAZO). American Society of Clinical Oncology; 2017.

30. Walsh CS. Two decades beyond BRCA1/2: Homologous recombination, hereditary cancer risk and a target for ovarian cancer therapy. Gynecol Oncol 2015; 137: 343-350

31. Farmer H, McCabe N, Lord CJ, et al. Targeting the DNA repair defect in BRCA mutant cells as a therapeutic strategy. Nature 2005; 434: 917-921

32. Pommier Y, O'Connor MJ, de Bono J. Laying a trap to kill cancer cells: PARP inhibitors and their mechanisms of action. Sci Transl Med 2016; 8: 362ps17-362ps17

33. Sonnenblick A, De Azambuja E, Azim HA Jr, et al. An update on PARP-inhibitors: moving to the adjuvant setting. Nat Rev Clin Oncol. 2015; 12: $27-$ 41.

34. Kim G, Ison G, McKee AE, et al. FDA approval summary. olaparib monotherapy in patients with deleterious germline BRCA Mutated advanced ovarian cancer treated with three or more lines of chemotherapy, Clin Cancer Res 2015; 21: 42574261.

35. Menear KA, Adcock C, Boulter R, et al. 4-[3-(4cyclopropanecarbonylpiperazine-1-carbonyl)-4fluorobenzyl]-2H-phthalazin- 1-one: a novel bioavailable inhibitor of poly(ADP-ribose) polymerase-1, J Med Chem 2008; 51: 6581-6591.

36. Thomas HD, Calabrese CR, Batey MA, et al. Preclinical selection of a novel poly(ADP-ribose) polymerase inhibitor for clinical trial. Mol Cancer Ther 2007; 6: 945-956.

37. Robillard L, Nguyen M, Harding TC, et al. In vitro and in vivo assessment of the mechanism of action of the PARP inhibitor rucaparib, AACR 2017 Proceedings 2017; Abstracts 1-3062. 2017; abstract 2475.
38. Jones P, Altamura S, Boueres J, et al. Discovery of 2-\{4-[(3S)-piperidin-3-yl]phenyl $\}-2 \mathrm{H}$-indazole-7carboxamide (MK4827): a novel oral poly(ADPribose)polymerase (PARP) inhibitor efficacious in BRCA-1 and -2 mutant tumors. J Med Chem 2009; 52: 7170-7185.

39. Shen Y, Rehman FL, Feng Y, et al. BMN 673, a novel and highly potent PARP1/2 inhibitor for the treatment of human cancers with DNA repair deficiency. Clin. Cancer Res 2013; 19: 5003-5015.

40. Donawho CK, Luo Y, Penning TD, et al. ABT888, an orally active poly(ADP-ribose) polymerase inhibitor that potentiates DNA-damaging agents in preclinical tumor models. Clin Cancer Res 2007; 2728-2737.

41. National Center for Biotechnology Information. PubChem Database. Olaparib, CID $=23725625$, https://pubchem.ncbi.nlm.nih.gov/compound/2372 5625 (accessed on Mar. 26, 2019).

42. National Center for Biotechnology Information. PubChem Database. Rucaparib, CID=9931954, https://pubchem.ncbi.nlm.nih.gov/compound/9931 954 (accessed on Mar. 26, 2019).

43. National Center for Biotechnology Information. PubChem Database. Niraparib, CID $=24958200$, https://pubchem.ncbi.nlm.nih.gov/compound/2495 8200 (accessed on Mar. 26, 2019).

44. National Center for Biotechnology Information. PubChem Database. Talazoparib, CID $=135565082$, https://pubchem.ncbi.nlm.nih.gov/compound/1355 65082 (accessed on Mar. 26, 2019).

45. National Center for Biotechnology Information. PubChem Database. Veliparib, CID $=11960529$, https://pubchem.ncbi.nlm.nih.gov/compound/1196 0529 (accessed on Mar. 26, 2019).

46. Brown JS, Kaye SB, Yap TA. PARP inhibitors: the race is on. Br J Cancer 2016; 114: 713-715.

47. Deeks ED. Olaparib: first global approval. Drugs 2015; 75: 231-240.

48. O'Connor MJ. Targeting the DNA damage response in cancer. Mol Cell 2015; 60: 547-560.

49. Dollery CT. Intracellular drug concentrations, Clin Pharmacol Ther 2013; 93: 263-266.

50. Lupo B, Trusolino L. Inhibition of poly(ADPribosyl)ation in cancer: old and new paradigms revisited. Biochim Biophys Acta 2014; 1846: 201215.

51. Fojo T, Bates S. Mechanisms of resistance to PARP inhibitors-three and counting. Cancer Discov 2013; 3: 20-23.

52. Lord CJ, Ashworth A. Mechanisms of resistance to therapies targetingBRCA-mutant cancers. Nat Med 2013; 19: 1381-1388. 
53. Dufour R, Daumar P, Mounetou E, et al. BCRP and $\mathrm{P}$-gp relay overexpression in triple negative basallike breast cancer cell line: a prospective role in resistance to Olaparib, Sci Rep 2015; 5: 12670.

54. Zhou Y, Joubran C, Miller-Vedam L, et al. Thinking outside the bug: a unique assay to measure intracellular drug penetration in gram-negative bacteria. Anal Chem 2015; 87: 3579-3584.

55. Colletti LM, Liu Y, Koev G, et al. Methods to measure the intracellular concentration of unlabeled compounds within cultured cells using liquid chromatography/tandem mass spectrometry. Anal Biochem 2008; 383: 186-193.

56. Mateus A, Matsson P, Artursson P. Rapid measurement of intracellular bound drug concentrations. Mol Pharm 2013; 10: 2467-2478.

57. Durmus S, Sparidans SW, Van Esch A, et al. Breast cancer resistance protein (BCRP/ABCG2) and Pglycoprotein(P-GP/ABCB1) restrict oral availability and brain accumulation of the PARPinhibitor rucaparib (AG-014699). Pharm Res 2015; 32: 37-46.

58. Nijenhuis CM, Lucas L, Rosing $\mathrm{H}$, et al. Development and validation of a high-performance liquid chromatography-tandem mass spectrometry assay quantifying olaparib in human plasma. J Chromatogr 2013; B940: 121-125.

59. Sparidans RW, Durmus S, Schinkel AH, et al. Liquid chromatography-tandem mass spectrometric assay for the PARP inhibitor rucaparib in plasma. J Pharm Biomed Anal 2014; 88: 626-629.

60. Sparidans RW, Martens I, Valkenburg-Van Iersel $\mathrm{LW}$, et al. Liquid chromatography-tandem mass spectrometric assay for the PARP-1 inhibitor olaparib in combination with the nitrogen mustard melphalan in human plasma. J Chromatogr 2011; B879: 1851-1856.

61. Roth J, Peer CJ, Mannargudi B, et al. A sensitive and robust Ultra HPLC assay with tandem mass spectrometric detection for the quantitation of the PARP inhibitor olaparib (AZD2281) in human plasma for pharmacokinetic application. Chromatography 2014; 1: 82-95.

62. Oplustilova L, Wolanin K, Mistrik M, et al. Evaluation of candidate biomarkers to predict cancer cell sensitivity or resistance to PARP1inhibitor treatment. ABBV Cell Cycle 2012; 11: 3837-3850.

63. Wu $\mathrm{D}$, Wang $\mathrm{C}$, Yang $\mathrm{J}$, et al. Improving the intracellular drug concentration in lung cancer treatment through the delivery of doxorubicin and miR-519c mediated by porous PLGA microparticle. Mol Pharm 2016; 13: 3925-3933.
64. Bourgne C, Bamdad M, Janel A, et al. Measurement of imatinib uptake by flow cytometry. Cytometry 2012; A81: 996-1004.

65. Deng B, Wang Z, Song J, et al. Analysis of doxorubicin uptake in single human leukemia K562 cells using capillary electrophoresis coupled with laser-induced fluorescence detection. Anal Bioanal Chem 2011; 401: 2143-2152.

66. Daumar P, Dufour R, Dubois C, et al. Development and validation of a high-performance liquid chromatography method for the quantitation of intracellular PARP inhibitor Olaparib in cancer cells. J Pharm Biomed Anal 2018; 152: 74-80.

67. Trim PJ, Francese S, Clench MR. Imaging mass spectrometry for the assessment of drugs and metabolites in tissue. Bioanalysis 2009; 1: 309-319.

68. Nies AT, Koepsell H, Damme K, et al. Organic cation transporters (OCTs, MaTEs), in vitro and in vivo evidence for the importance in drug therapy. Handb Exp Pharmacol 2011; 201: 105-167.

69. Mateus A, Gordon LJ, Wayne GJ, et al. Prediction of intracellular exposure bridges the gap between target- and cell-based drug discovery. Proc Natl Acad Sci USA 2017; 114: E6231-E6239.

70. Dufour R, Daumar P, Mounetou E, et al. BCRP and P-gp relay overexpression in triple negative basallike breast cancer cell line: a prospective role in resistance to Olaparib. Sci Rep 2015; 5: 12670.

71. Lee JM, Peer CJ, Yu M, et al. Sequence-specific pharmacokinetic and pharmacodynamic phase $\mathrm{I} / \mathrm{Ib}$ study of olaparib tablets and carboplatin in women's cancer. Clin Cancer Res 2017; 23: 13971406.

72. Plummer R, Swaisland H, Leunen K, et al. Olaparib tablet formulation: effect of food on the pharmacokinetics after oral dosing in patients with advanced solid tumors. Cancer Chemother Pharmacol 2015; 76: 723-729.

73. Mostafa NM, Chiu YL, Rosen LS, et al. A phase 1 study to evaluate the effect of food on veliparib pharmacokinetics and relative bioavailability in subjects with solid tumors. Cancer Chemother Pharmacol 2014; 74: 583-591.

74. Wiegand R, Wu J, Sha X, et al. Simultaneous determination of ABT-888, a poly (ADP-ribose) polymerase inhibitor, and its metabolite in human plasma by liquid chromatography/ tandem mass spectrometry. J Chromatogr B Analyt Technol Biomed Life Sci 2010; 878: 333-339.

75. Sandhu SK, Schelman WR, Wilding G, et al. The poly(ADP-ribose) polymerase inhibitor niraparib (MK4827) in BRCA mutation carriers and patients 
with sporadic cancer: a phase 1 dose-escalation trial. Lancet Oncol 2013; 14: 882-892.

76. van Andel L, Zhang Z, Lu S, et al. Human mass balance study and metabolite profiling of 14Cniraparib, a novel poly(ADP-Ribose) polymerase (PARP)-1, and PARP-2 inhibitor, in patients with advanced cancer. Investig New Drugs 2017.

77. Ottria R, Ravelli A, Miceli M, et al. Quantitative Characterization of Olaparib in Nanodelivery System and Target Cell Compartments by LCMS/MS. Molecules 2019; 24: 989.

78. U.S. Food and Drug Administration, Department of Health and Human Services, http://www.fda.gov/downloads/Drugs/../Guidances /ucm070107.pdf (2001) (Accessed 3 April 2019).

79. Giacomini, Kathleen M., Shiew-Mei H, et al. Membrane transporters in drug development. Nature reviews Drug discovery 2010; 9: 215.
80. Chu, X., Korzekwa K, Elsby R, et al. Intracellular drug concentrations and transporters: measurement, modeling, and implications for the liver. Clin Pharmacol Therap 2013; 94: 126-141.

81. Nakagawa, Masayuki, Schneider E, et al. Reduced intracellular drug accumulation in the absence of $\mathrm{P}$ glycoprotein (mdr1) overexpression in mitoxantrone-resistant human MCF-7 breast cancer cells. Cancer Res 1992; 52: 6175-6181.

82. Yoshiyuki Y, Galetin A, Houston JB. Kinetic characterization of rat hepatic uptake of 16 actively transported drugs. Drug Metab Disposition 2011; 39: 1808-1814.

83. Karelle M, Kenworthy KE, et al. Simultaneous assessment of uptake and metabolism in rat hepatocytes: a comprehensive mechanistic model. J Pharmacol Exp Therap 2012; 341: 2-15.

This manuscript was peer-reviewed

Mode of Review: Single-blinded

Academic Editor: Dr. MA Jahangir

Copyright: (C2020 Phiri M, et al. This article is distributed under the terms of the Creative Commons Attribution 4.0 International License (http://creativecommons.org/licenses/by/4.0/), which permits unrestricted use, distribution, and reproduction in any medium, provided you give appropriate credit to the original author(s) and the source, provide a link to the Creative Commons license, and indicate if changes were made. 